\title{
Synthesis of Zinc Oxide Nanoparticles for Oil Upgrading and Wax Deposition Control: Effect of Calcination Temperature
}

\author{
Siti Nurliyana Che Mohamed Hussein ${ }^{1, *}$, Fatin Syahirah Mohamed Fuad ${ }^{1}$, and Marina Ismail ${ }^{2}$ \\ ${ }^{1}$ Faculty of Chemical Engineering, Universiti Teknologi MARA (UiTM), 40450 Shah Alam, Selangor Darul Ehsan, Malaysia \\ ${ }^{2}$ Academy of Language Studies, Universiti Teknologi MARA (UiTM), 40450 Shah Alam, Selangor Darul Ehsan, Malaysia
}

*Corresponding author:

tel: $+6012-5283517$

email: siti.nurliyana@uitm.edu.my

Received: February 4, 2019

Accepted: October 25, 2019

DOI: $10.22146 / \mathrm{ijc} .43317$

\begin{abstract}
In this study, $\mathrm{ZnO}$ nanoparticles were synthesized using a sol-gel method for oil upgrading and wax deposition control. The synthesized $\mathrm{ZnO}$ nanoparticles were used to measure viscosity and wax deposition in the heavy crude oil and to investigate the effectiveness of the nanoparticles in the reduction of viscosity and wax deposition control of the heavy crude oil. This study investigated the effect of calcination temperature on $\mathrm{ZnO}$ nanoparticles during synthesis towards viscosity reduction and wax deposition control. $\mathrm{ZnO}$ nanoparticles were calcined at different temperatures ranging from 300 to $900{ }^{\circ} \mathrm{C}$. The calcined $\mathrm{ZnO}$ nanoparticles were characterized using X-ray diffraction (XRD), Field Emission Scanning Electron microscope (FESEM), and Energy-dispersive Xray spectroscopy (EDX) for its structure, size, shape, and morphology. The characterization results showed a hexagonal wurtzite structure of $\mathrm{ZnO}$ nanoparticles. The physical properties and rheology of heavy crude oil were characterized by using Electronic Rheometer and cold finger method to analyze the viscosity, shear rate, and wax deposition of the heavy crude oil for performance study. Decreased in crystallite size from 15.59 to $12.84 \mathrm{~nm}$ was observed with increasing calcination temperature from 300 to $400{ }^{\circ} \mathrm{C}$, and a further increase of calcination temperature from 400 to $900{ }^{\circ} \mathrm{C}$, the crystallite size increased from 12.84 to $41.58 \mathrm{~nm}$. The degree viscosity reduction (DVR \%) of heavy crude oil was observed to increase by $41.7 \%$, with decreasing $\mathrm{ZnO}$ nanoparticles size from 30.11 $\mathrm{nm}$ to $12.84 \mathrm{~nm}$. The optimum calcination temperature was $400{ }^{\circ} \mathrm{C}$. Wax deposition decreases by $32.40 \%$ after the addition of $\mathrm{ZnO}$ nanoparticles into heavy crude oil.
\end{abstract}

Keywords: zinc oxide ( $\mathrm{ZnO})$; nanoparticles; calcination; wax content; viscosity reduction

\section{- INTRODUCTION}

Wax deposition in heavy crude oil has always brought a significant impact on the petroleum industry, especially in the transportation and production section. There are various effects of wax deposition in heavy crude oil that we should be concerned about, for example, nonNewtonian flow characteristics of the fluid, increased pumping power, decreased flow rate, or even to the total blockage of the pipeline [1]. Wax precipitation induced by the viscosity of heavy crude oil that increases can cause flow line pressure to drop, leading to low flow rates [2]. In turn, this makes conditions for wax deposition in the pipes more favorable. Serious wax deposition in heavy crude oil needs extra attention since it may cause harm not only to the transportation and production section, but also to the petroleum economy as well. There are many advanced technology and chemicals for wax prevention and removals, such as wax crystal modifiers and dispersants. However, these methods have disadvantages, such as cost and limited to one well [1]. $\mathrm{ZnO}$ nanotechnology has introduced a more effective solution for the petroleum industry as it provided simple and cheaper technology. Hence, it has become a major interest nowadays to reduce wax deposition from the heavy crude oil, to avoid its bad effect on the petroleum industry as well as to the environment.

Wax deposition in pipelines is commonly caused by several factors such as temperature, flow rate, oil 
composition, and shear rate [3]. Generally, wax precipitation and deposition are related to the wax content of heavy crude oil. As the temperature increases, the viscosity of the crude oil decreases. In oil composition, the API gravity plays an important role in the petroleum industry as it is related to the wax deposition [4]. A high API gravity shows that crude oil has low wax content. An API gravity that is greater than 10 indicates light crude oil, whereas an API gravity of less than 10 indicates heavy crude oil [5]. Basically, the heavier the crude oil, the higher wax content.

In this study, the focus will be given on the heavy crude oil from the petroleum industry, such as in transportation and production. It is well known that this heavy crude oil releases a higher significant deposition of wax content. The wax that is present in the heavy crude oil primarily consists of paraffin hydrocarbons $\left(\mathrm{C}_{18}-\mathrm{C}_{36}\right)$ known as paraffin wax and naphthenic hydrocarbons $\left(\mathrm{C}_{30}-\mathrm{C}_{60}\right)$ [6]. The factor that leads to wax deposition problems depends on the type of oil and the molecular composition of the wax molecules. The waxes in crude oils are often more challenging to control because the alkane chains are often longer in the crude oil [7].

Currently, various conventional methods have been used to remove the wax precipitate in heavy crude oil, such as thermal techniques, chemical techniques, mechanical techniques, and thermo-chemical packages [1]. However, these conventional methods have some downside with their process in removing or preventing the wax precipitate from heavy crude oil [8]. For example, electric heaters can cause an increase in maintenance costs, and the availability of electrical power is limited, while chemical techniques, such as dispersants, could lead to harmful erosion [1].

Numerous transition metals have been used in many applications such as iron and zinc because of its heat and electric conductivity [9]. In addition, these metals are commonly used as catalytic agents due to their ability to change their state or absorb other substances on their surface and activate them in the process [9].

Numerous methods have been described in research to synthesize $\mathrm{ZnO}$ nanoparticles, such as the sol-gel method, co-precipitation, and spray pyrolysis [10].
However, in this study, the sol-gel process was more preferred than the other methods because of its low cost and simple [11].

\section{- EXPERIMENTAL SECTION}

\section{Materials}

Crude oil obtained from Kemaman Bitumen Company Sdn. Bhd. (KBC) was used as received for characterization and rheological tests to analyze its properties. Zinc acetate dihydrate $\left(\mathrm{Zn}\left(\mathrm{CH}_{3} \mathrm{COO}\right)_{2} \cdot 2 \mathrm{H}_{2} \mathrm{O}\right)$, oxalic acid $\left(\mathrm{C}_{2} \mathrm{H}_{4} \mathrm{O}_{4} \cdot 2 \mathrm{H}_{2} \mathrm{O}\right)$, and ethanol $\left(\mathrm{C}_{2} \mathrm{H}_{5} \mathrm{OH}\right) 95 \%$ AR Grade obtained from Vchem Laboratory Chemicals, ammonia solution acquired from Daejung Chemicals. The other chemicals such as hydrochloric acid $(\mathrm{HCl})$, methanol $\left(\mathrm{CH}_{3} \mathrm{OH}\right), n$-heptane $\left(\mathrm{C}_{7} \mathrm{H}_{16}\right)$, and toluene $\left(\mathrm{C}_{7} \mathrm{H}_{8}\right)$ also obtained from the Vchem Laboratory Chemicals.

\section{Instrumentation}

High-Resolution X-ray Diffractometer (PANalytical X'Pert PRO MRD) was used to analyze the crystallinity of the zinc oxide nanoparticles. Energy Dispersive X-ray Spectroscopy (EDX) was used in this study to verify the elemental composition of nanoparticles sample. The surface morphology of $\mathrm{ZnO}$ nanoparticles was determined using Field Emission scanning electron microscopy (FESEM). The rheological measurement was carried out using a Rheometer Paar Physica MCR300.

\section{Procedure}

\section{Characterization of crude oil}

The sample of crude oil studied in this work was obtained from Kemaman Bitumen Company (KBC) Sdn Bhd. Table 1 shows the physical properties and composition of crude oil in weight percentage (\%) of the sample crude oil that was obtained from KBC. The density of crude oil was determined by using Eq. (1) and Eq. (2) where S.G., $\rho_{\text {oil }}$, and $\rho_{\text {water }}$ are the specific gravity, oil density, and water density, respectively. The API gravity of crude oil refers to the density of the fluid after the gas been liberated from the fluid at ambient pressure and reservoir temperature [12]. Crude oil gained from the $\mathrm{KBC}$ was considered heavy crude oil because of API 
Table 1. Physical properties and composition of crude oil

\begin{tabular}{lc}
\hline Physical properties & \\
\hline Density $\left(\mathrm{kg} / \mathrm{m}^{3}\right)$ & 999 \\
Specific gravity, SG & 0.999 \\
$\mathrm{API}^{\circ}$ & 11 \\
Viscosity at $40{ }^{\circ} \mathrm{C}(\mathrm{cP})$ & 17,751 \\
Color & Black \\
Cloud Point $\left({ }^{\circ} \mathrm{C}\right)$ & 12 \\
\hline Composition & $\mathrm{Wt} . \%$ \\
\hline Saturates & 3.0 \\
Aromatic & 63.4 \\
Resin & 12.9 \\
Asphaltenes & 20.7 \\
\hline
\end{tabular}

and density value of mostly heavy oil ranging between $10^{\circ}$ to $22^{\circ}$ API and 920 to $1000 \mathrm{~kg} / \mathrm{m}^{3}$ [13].

$$
\begin{aligned}
& \mathrm{API}^{\circ}=\frac{141.5}{\mathrm{~S} . \mathrm{G}}-131.5 \\
& \text { S.G. }=\frac{\rho_{\text {oil }}}{\rho_{\mathrm{H}_{2} \mathrm{O}}}
\end{aligned}
$$

\section{Synthesis of zinc oxide nanoparticles}

$\mathrm{ZnO}$ nanoparticles were prepared under constant processing conditions of $\mathrm{pH}$, zinc acetate, oxalic acid ratio, and drying temperature by using a sol-gel method. Zinc acetate $\left[\mathrm{Zn}\left(\mathrm{CH}_{3} \mathrm{COOH}\right)_{2} \cdot 2 \mathrm{H}_{2} \mathrm{O}\right]$, oxalic acid $\left[\mathrm{C}_{2} \mathrm{H}_{2} \mathrm{O}_{4}\right]$, and ethanol $\left[\mathrm{CH}_{3} \mathrm{CH}_{2} \mathrm{OH}\right]$ were used as precursor materials for the preparation of $\mathrm{ZnO}$ nanoparticles $[10,14]$. In addition, the effect of calcination temperature was studied during the synthesis of $\mathrm{ZnO}$ nanoparticles by varying its temperature from 300 to $900{ }^{\circ} \mathrm{C}$ [15-16]. For the preparation of $\mathrm{ZnO}$ nanoparticles with molar ratios of 1:2 of zinc acetate and oxalic acid, $2 \mathrm{~g}$ of zinc acetate was added to the $100 \mathrm{~mL}$ of ethanol solution (+ $10 \%$ volume of water) in $500 \mathrm{~mL}$ glass beaker in a water bath at $65{ }^{\circ} \mathrm{C}$ under reflux condition for $30 \mathrm{~min}$. An amount of $1.64 \mathrm{~g}$ of oxalic acid powder was added to the $100 \mathrm{~mL}$ of ethanol solution in $500 \mathrm{~mL}$ glass beaker at $45^{\circ} \mathrm{C}$ under $700 \mathrm{rpm}$ speed for $30 \mathrm{~min}$. Then, the oxalic acid solution was slowly added by using a burette to the zinc acetate solution in $500 \mathrm{~mL}$ glass beaker under vigorous stirring at $1000 \mathrm{rpm}[10,17]$. The final $\mathrm{pH}$ of the reactant was kept at 3 by adding a required amount of hydrochloric acid and ammonia solution, respectively. Then, the solution was kept undisturbed for a while till white precipitates were seen in the solution and filter the precipitate by using a vacuum pump. The precipitate was dried at $80^{\circ} \mathrm{C}$ for $2 \mathrm{~h}$ in a sintering boat which was put in a drying oven, and then calcined at $300^{\circ} \mathrm{C}$ for $2 \mathrm{~h}$ in a sintering boat in the furnace to obtain a smoother powder [11]. The calcination of the $\mathrm{ZnO}$ precipitate was repeated but at different calcination temperatures between 400 to $900{ }^{\circ} \mathrm{C}$.

\section{Characterization of ZnO nanoparticles}

The X-ray diffraction analysis was carried out for the synthesized $\mathrm{ZnO}$ nanoparticles by using a HighResolution X-ray Diffractometer (PANalytical X'Pert PRO MRD) with $\mathrm{Cu}$ Ka radiation $(\lambda=1.54060 \AA$ ) over the angle $2 \theta$ range of $10^{\circ}-90^{\circ}$ [10]. X-ray diffraction was used to analyze the crystallinity of zinc oxide nanoparticles. The XRD patterns indicate the formation of the crystal structure. The diffraction angle used for the $\mathrm{ZnO}$ nanoparticles sample was from $10^{\circ}$ to $90^{\circ}$. In this study, the intensity peaks and diffraction angle of calcined $\mathrm{ZnO}$ at 300 to $900{ }^{\circ} \mathrm{C}$ were investigated to determine the effect of calcination temperature on the crystallite size of $\mathrm{ZnO}$ nanoparticles.

Other than XRD, field-emission scanning electron microscope (FESEM) and energy dispersive X-ray (EDX) were also used to study the characteristic of these nanoparticles by analyzing their morphological structure and composition element of the $\mathrm{ZnO}$ nanoparticles. The morphological structure of $\mathrm{ZnO}$ nanoparticles was determined by using a highresolution scanning electron (Zeiss, Supra40VP) with the magnification of 10,000 .

The crystallite size of $\mathrm{ZnO}$ nanoparticles was then estimated by using the Debye-Scherer formula given in Eq. (3), where 0.89 is Scherer's constant, $\lambda$ is the wavelength of $\mathrm{X}$-rays, $\theta$ is the Bragg diffraction angle, and $B$ is the full width at half-maximum (FWHM) of the diffraction peak [18].

$\mathrm{D}=\frac{0.89 \lambda}{\mathrm{B} \cos \theta}$

\section{Rheological measurements}

$\mathrm{ZnO}$ nanoparticles $(0.4 \mathrm{~g})$ was added to the heavy crude oil. The tests were performed at a different temperature ranging between 30,45 , and $60{ }^{\circ} \mathrm{C}$. This 
experiment was run in a controlled condition: shear rate between 0 and $500 \mathrm{~s}^{-1}$ at $24.85^{\circ} \mathrm{C}$. Shear rate and apparent viscosity values were obtained every $10 \mathrm{sec}$, resulting in 28 points, respectively. For performance study, the effect of $\mathrm{ZnO}$ nanoparticle's size and temperature at a higher shear rate on the viscosity reduction of heavy crude oil were investigated by using this equipment.

\section{- RESULTS AND DISCUSSION}

\section{Characterization of Synthesized Zinc Oxide Nanoparticles}

\section{$X$-ray diffraction (XRD)}

XRD was used to characterize the crystalline nature of the $\mathrm{ZnO}$ nanoparticles. Fig. 1 shows XRD patterns of $\mathrm{ZnO}$ nanoparticles calcined at different temperatures ranging from 300 to $900{ }^{\circ} \mathrm{C}$. The presence of highintensity peaks corresponds to the (100), (002), and (101) lattice plane confirms the formation of the hexagonal wurtzite structure of the $\mathrm{ZnO}$ nanoparticles. The peaks gained in this study perfectly matches with the standard peaks of $\mathrm{ZnO}$ powder diffraction (JCPDS 36-1451). All the diffraction peaks of $\mathrm{ZnO}$ nanoparticles at different calcination temperatures were observed at $2 \theta$ : $31.95^{\circ}, 34.7^{\circ}, 36.4^{\circ}, 47.8^{\circ}, 56.9^{\circ}, 63.1^{\circ}, 66.5^{\circ}, 68.1^{\circ}$, and $69.3^{\circ}$, that attributed to the (100), (002), (101), (102), (110), (103), (200), (112), and (201) crystal planes of the hexagonal $\mathrm{ZnO}$ powder. Fig. 1 suggests that, with an increase in calcination temperature, the intensity of diffraction peaks increases, which indicates the strengthening of the $\mathrm{ZnO}$ phase [11].

The obtained crystallite size of $\mathrm{ZnO}$ nanoparticles was tabulated in Table 2. The decrease in crystallite size from 15.59 to $12.84 \mathrm{~nm}$ was observed with an increase in calcination temperature from 300 to $400{ }^{\circ} \mathrm{C}$. However, the crystallite size continued to increase from 12.84 to $41.58 \mathrm{~nm}$ by a further increase in calcination temperature from 400 to $800{ }^{\circ} \mathrm{C}$. The average crystallite size of $\mathrm{ZnO}$ nanoparticles was found to be $25.42 \mathrm{~nm}$. The decrease in crystallite size at low temperature indicates the restructuring process, whereas the increase in calcination temperature with an increase in crystallite size suggests the strengthening of the $\mathrm{ZnO}$ nanoparticles phase [11]. In addition, by referring to Fig. 1, the spectrum became sharper, and diffraction peak became narrower with the increase in the temperature from 400 to $800{ }^{\circ} \mathrm{C}$, indicating that the crystallite $\mathrm{ZnO}$ nanoparticles formation has been established due to growth rate between the crystallographic planes [16,19-21].

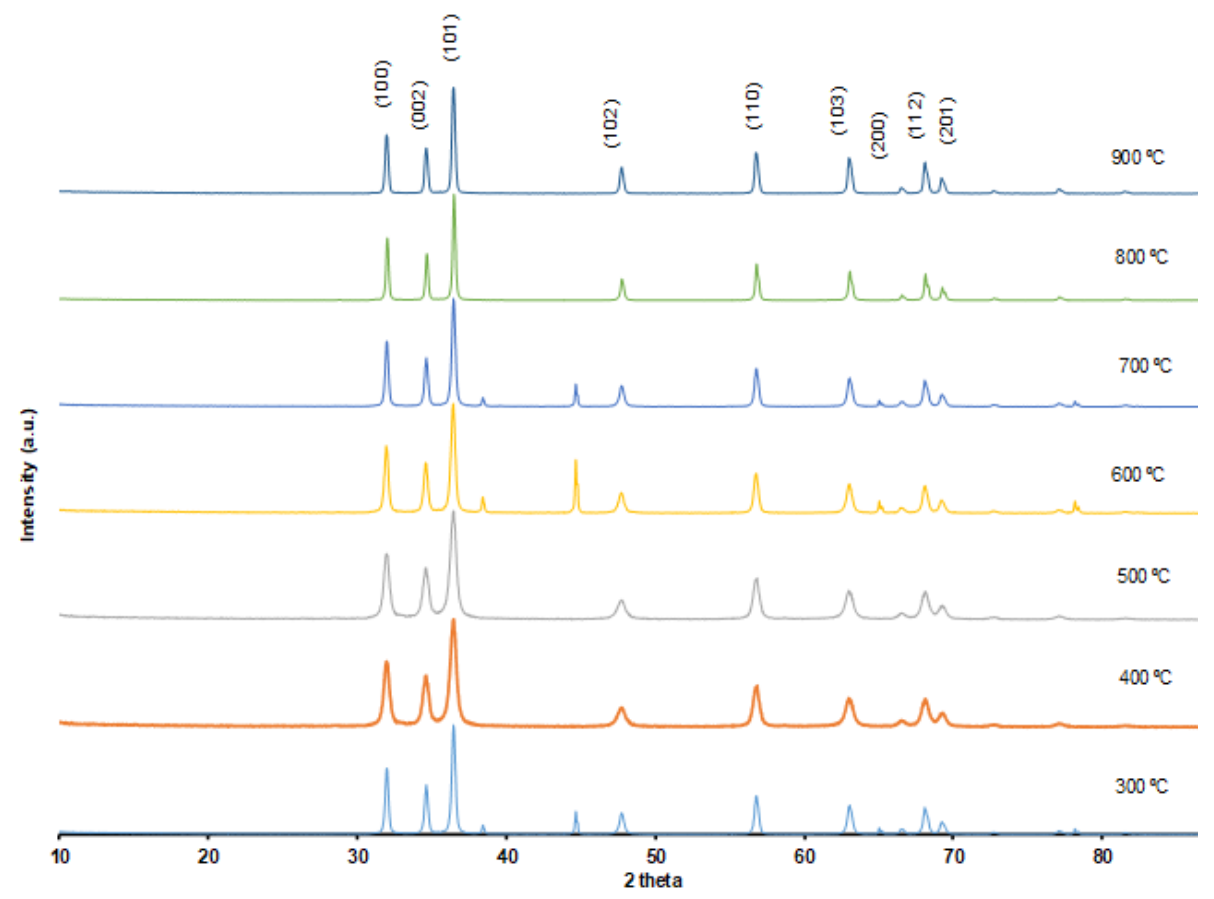

Fig 1. XRD patterns of the $\mathrm{ZnO}$ nanoparticles calcined at $300,400,500,600,700,800$, and $900{ }^{\circ} \mathrm{C}$. 
Table 2. XRD analysis of $\mathrm{ZnO}$ nanoparticles: Full width at half-maximum (B) and size (nm) for each degree

\begin{tabular}{cccc}
\hline $\begin{array}{c}\text { Temperature } \\
\left({ }^{\circ} \mathrm{C}\right)\end{array}$ & $\begin{array}{c}\text { Position } \\
2 \theta\left({ }^{\circ}\right)\end{array}$ & $\begin{array}{c}\text { Full width at half- } \\
\text { maximum }(\mathrm{B})\end{array}$ & $\begin{array}{c}\text { Size } \\
(\mathrm{nm})\end{array}$ \\
\hline 300 & 36.4 & 0.56 & 15.59 \\
400 & 36.4 & 0.68 & 12.84 \\
500 & 36.4 & 0.47 & 18.58 \\
600 & 36.4 & 0.34 & 25.68 \\
700 & 36.4 & 0.29 & 30.11 \\
800 & 36.4 & 0.21 & 41.58 \\
900 & 36.4 & 0.26 & 33.58 \\
\hline
\end{tabular}

\section{Energy dispersive X-ray spectroscopy (EDX)}

EDX was used in this study to verify the elemental composition of the nanoparticles synthesized by using the sol-gel method. Table 3 shows the weight and atomic percentage of EDX of the $\mathrm{ZnO}$ element, which suggests the good purity of the $\mathrm{ZnO}$ powder. Therefore, the experimental synthesis of zinc oxide nanoparticles sample was successful due to the presence of zinc and oxygen elements, respectively.

These results show that the final product was pure $\mathrm{ZnO}$ nanoparticles. According to Al-Hada et al. [19], by using zinc nitrate as a precursor, the atomic percentages of $\mathrm{Zn}$ and $\mathrm{O}$ were approximately $50.13 \%$ and $49.87 \%$. From this comparison, it showed that the precursor of zinc acetate produces a higher atomic percentage of $\mathrm{Zn}$ than precursor zinc nitrate. However, the value of the atomic percentage of $\mathrm{Zn}$ and $\mathrm{O}$ between both precursors did not create a huge difference.

\section{Effect of Calcination Temperature on Size of Zinc Oxide Nanoparticles}

Fig. 2 shows the crystallite size of the $\mathrm{ZnO}$ as a function of calcination temperature ranging between 300 to $900^{\circ} \mathrm{C}$. As calcination temperature increases from 300 to $400{ }^{\circ} \mathrm{C}$, the crystallite size of $\mathrm{ZnO}$ decreases. The decrease in the crystallite size of $\mathrm{ZnO}$ from 15.59 to $12.84 \mathrm{~nm}$ was due to the structural rearrangement, which indicates a restructuring process [10-11]. However, the crystallite size of $\mathrm{ZnO}$ tends to increase from 12.84 to $41.58 \mathrm{~nm}$ with increasing calcination temperature from 400 to $800^{\circ} \mathrm{C}$, which implies the strengthening of the $\mathrm{ZnO}$ phase. This was because of the increment of the crystallite volume to the surface ratio $[11,19]$. The minimum crystallite size of $\mathrm{ZnO}$ in this study was achieved at a temperature of $400{ }^{\circ} \mathrm{C}$, whereas the maximum one was achieved at $800^{\circ} \mathrm{C}$.

\section{Effect of Calcination Temperature on the Morphology of the Nanoparticles}

Fig. 3 shows FESEM images of the $\mathrm{ZnO}$ nanoparticles at different calcination temperature. Fig. 3(a) reveals that the synthesized sample has nanoparticles appearance with a rod-like morphology structure at lower temperature. Fig. 3(b) shows that the length of the

Table 3. Weight and atomic percentage of EDX of $\mathrm{ZnO}$ element

\begin{tabular}{lcc}
\hline Element & Wt.\% & Atomic \% \\
\hline $\mathrm{O}$ & 22.59 & 45.61 \\
$\mathrm{Zn}$ & 77.41 & 54.39 \\
\hline
\end{tabular}

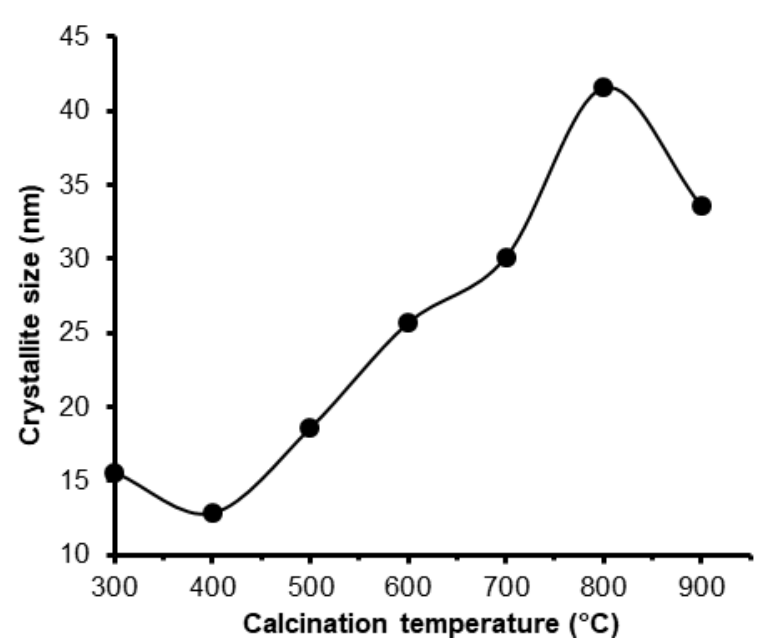

Fig 2. Variation in crystallite size with varying calcination temperatures. 

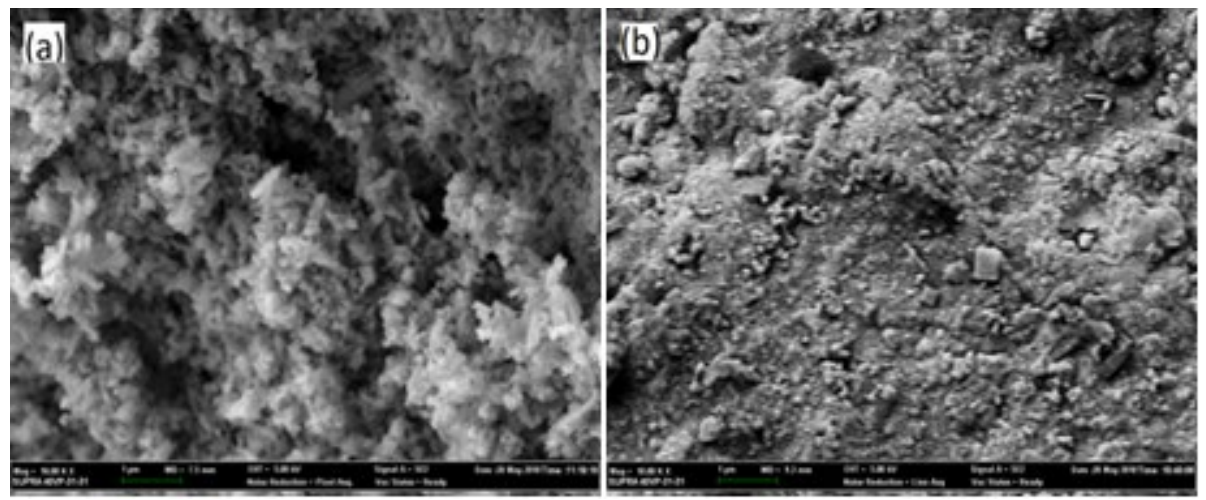

Fig 3. FESEM images of $\mathrm{ZnO}$ nanoparticles at calcination temperature of (a) $400{ }^{\circ} \mathrm{C}$ and (b) $500{ }^{\circ} \mathrm{C}$.

structure was reduced with the increase in the calcination temperature. The results are consistent with previous research stated that $\mathrm{ZnO}$ nanoparticles product started to crumble and overlapped in a proportional relation with the increase of calcination temperature [19-20,22].

\section{Effect of Nanoparticle Size towards Viscosity Reduction}

To further investigate the effect of the calcination temperature of the $\mathrm{ZnO}$ nanoparticles on the heavy crude oil, the reduction of viscosity of heavy crude oil was carried out. Fig. 4 shows the viscosity of the heavy crude oil in the presence of $\mathrm{ZnO}$ nanoparticles at different nanoparticle sizes at $30{ }^{\circ} \mathrm{C}$ and shear rate between 0 and $80 \mathrm{~s}^{-1}$. This indicates that the addition of $\mathrm{ZnO}$ nanoparticles into the heavy crude oil will reduce the viscosity of the

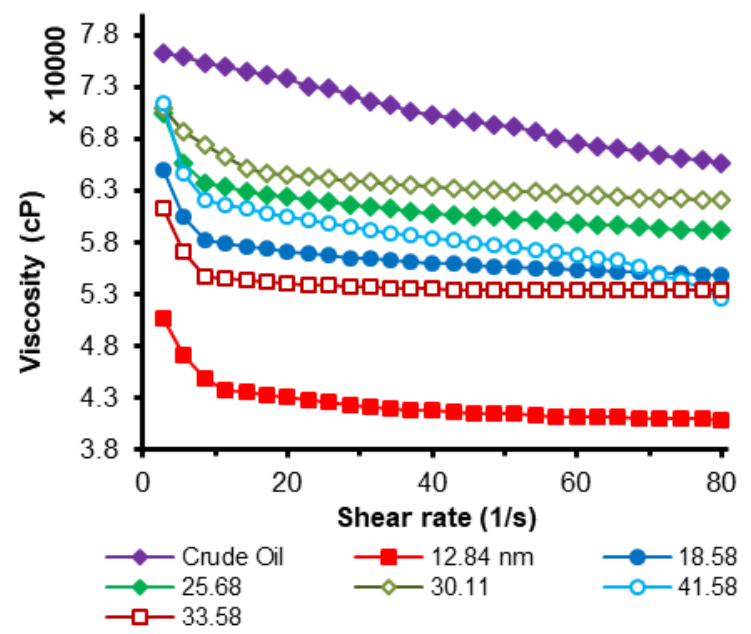

Fig 4. Viscosity of heavy crude oil in the presence of $\mathrm{ZnO}$ nanoparticles at different nanoparticles size at $30^{\circ} \mathrm{C}$ and shear rate between 0 and $80 \mathrm{~s}^{-1}$ heavy crude oil. The nanoparticle sizes evaluated in this study were $12.84,18.58,25.68,30.11,33.58$, and $41.58 \mathrm{~nm}$. It was observed that the viscosity of heavy crude oil decreased with a decrease in nanoparticle sizes. The highest viscosity reduction of heavy crude oil obtained at $12.84 \mathrm{~nm}$. As particle size increases, a decrease in performance was noticed [23]. This is due to fewer active sites available for nanoparticles to attach to heavy crude oil components [24].

The degree of viscosity reduction (DVR) was calculated by Eq. (4), where $\mu_{\mathrm{HO}}$ and $\mu_{\mathrm{np}}$ were the crude oil before and after additional nanoparticle values, measured at a shear rate between 0 and $80 \mathrm{~s}^{-1}$, respectively. Fig. 5 indicates the degree of viscosity reduction of heavy crude oil with the presence of the $\mathrm{ZnO}$ nanoparticles with different sizes, at $30^{\circ} \mathrm{C}$ and shear

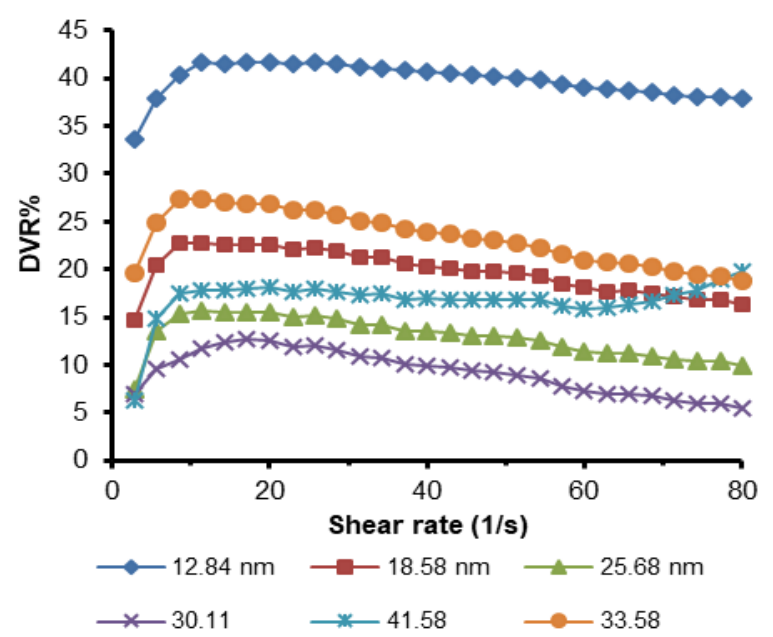

Fig 5. The degree of viscosity reduction of heavy crude oil with the presence of the $\mathrm{ZnO}$ nanoparticles with different sizes, at $30^{\circ} \mathrm{C}$ and shear rate between 0 and $80 \mathrm{~s}^{-1}$ 
rate between 0 and $80 \mathrm{~s}^{-1}$. The values of DVR indicate that the optimal nanoparticle size at which the biggest change in viscosity obtained was $12.84 \mathrm{~nm}$ for all shear rates. The lowest degree of viscosity reduction was $5.5 \%$, which occurred at $30.11 \mathrm{~nm}$, while the highest degree of viscosity reduction was $41.7 \%$ at $12.84 \mathrm{~nm}$. However, increasing the shear rate from 10 to $80 \mathrm{~s}^{-1}$ slightly reduced the DVR\%.

DVR $\%=\left(\frac{\mu_{\mathrm{HO}}-\mu_{\mathrm{np}}}{\mu_{\mathrm{np}}}\right) \times 100$

\section{Effect of Temperature and High Shear Rate on Heavy Crude Oil}

Temperature plays an important role in viscosity control of heavy crude oil, as increasing the temperature will reduce the viscosity of the oil. Fig. 5 shows that $\mathrm{ZnO}$ nanoparticles at $12.84 \mathrm{~nm}$ exhibit the best performances due to the higher percentage in viscosity reduction. Therefore, in this analysis of temperature and high shear rate effect, nanoparticles with a size of $12.84 \mathrm{~nm}$ were chosen to be evaluated at three different temperatures at high shear rates. The temperatures of 30,45 , and $60{ }^{\circ} \mathrm{C}$ were evaluated respectively, at shear rates between 0 and $500 \mathrm{~s}^{-1}$. Fig. 6 displays the rheological responses for heavy crude oil both with and without additional $\mathrm{ZnO}$ nanoparticles at 30,45 , and $60^{\circ} \mathrm{C}$, at shear rates between 0 and $500 \mathrm{~s}^{-1}$. The DVR for 30,45 , and $60^{\circ} \mathrm{C}$, and at shear rates between 0 and $500 \mathrm{~s}^{-1}$ are presented.

The rheological responses of heavy crude oil with additional $\mathrm{ZnO}$ nanoparticles at 30,45 , and $60^{\circ} \mathrm{C}$ shows the degree of viscosity reduction for heavy crude oil where the highest DVR was 71\%. Therefore, increase in the shear rate from 0 to $500 \mathrm{~s}^{-1}$ with increase in the temperature at 30,45 , and $60^{\circ} \mathrm{C}$ will decrease the DVR. The rheological behavior of heavy crude oil at $60{ }^{\circ} \mathrm{C}$ shows the minor changes in viscosity values between presence and absence of $\mathrm{ZnO}$ nanoparticles. Fig. 6 indicates that at temperature $30{ }^{\circ} \mathrm{C}$, the DVR tends to increase up to $71 \%$ with increasing shear rate from 100 to $400 \mathrm{~s}^{-1}$. However, at temperatures of 45 and $60{ }^{\circ} \mathrm{C}$, the DVR tends to decrease with an increase in shear rate from 100 to $400 \mathrm{~s}^{-1}$. From this observation, it can be concluded that the optimum temperature of this performance was at $45^{\circ} \mathrm{C}$, where the

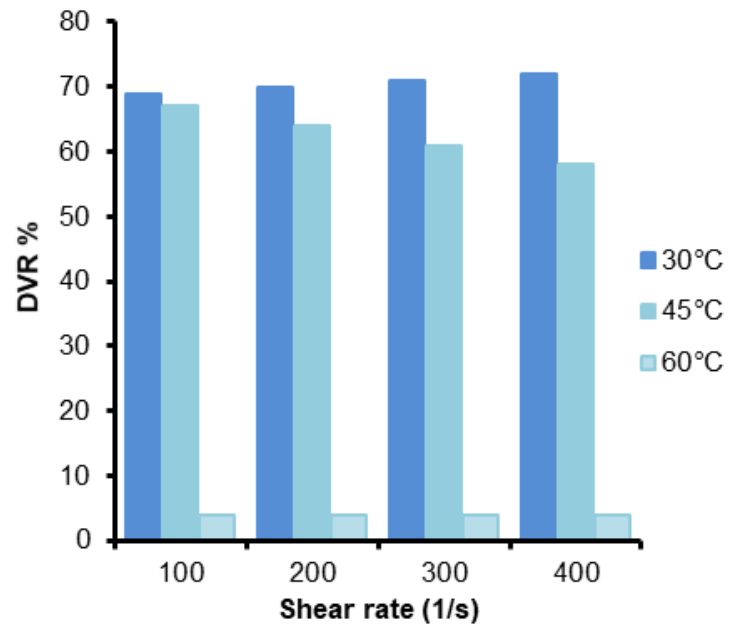

Fig 6. Degree of viscosity reduction at shear rates between 0 and $500 \mathrm{~s}^{-1}$ at different temperatures of 30, 45 and $60^{\circ} \mathrm{C}$

DVR was reduced nearly to $0 \%$ with further increase in the temperature. As the temperature increases, so does the rate of reaction of $\mathrm{ZnO}$ nanoparticles towards heavy crude oil. However, very high temperatures can denature the $\mathrm{ZnO}$ nanoparticles and change both the chemical and physical properties of the $\mathrm{ZnO}$ nanoparticles.

\section{- CONCLUSION}

$\mathrm{ZnO}$ nanoparticles were successfully synthesized by using the sol-gel method at different calcination temperatures from 300 to $900{ }^{\circ} \mathrm{C}$. The effect of calcination temperature on the structure and crystallite size of $\mathrm{ZnO}$ nanoparticles at different temperatures was studied by using XRD, FESEM, and EDX. The XRD results approved the presence of the formation of the hexagonal wurtzite structure of $\mathrm{ZnO}$ nanoparticles. The crystallinity increased with increasing calcination temperature. The crystallite size decreased (15.59 to $12.84 \mathrm{~nm}$ ) with an increase in calcination temperature from 300 to $400{ }^{\circ} \mathrm{C}$. Further increase in calcination temperature from 400 to $800{ }^{\circ} \mathrm{C}$ resulted in an increase in the crystallite size from 12.84 to $41.58 \mathrm{~nm}$. The synthesized sample was then used for viscosity reduction for oil upgrading, and it showed that nanoparticles at the size of $12.84 \mathrm{~nm}$ gave the best performances for viscosity reduction compared to the others. 


\section{- ACKNOWLEDGMENTS}

The author would like to thank Malaysian Ministry of Higher Education and Universiti Teknologi MARA (UiTM) for the Fundamental Research Grant Scheme (FRGS). (Project No.: 600-IRMI/FRGS 5/3 (048/2019)). Special thanks to Kemaman Bitumen Complex (KBC) for their supply of heavy oil to realize this research.

\section{- REFERENCES}

[1] Sousa, A.L., Matos, H.A., and Guerreiro, L.P., 2019. Preventing and removing wax deposition inside vertical wells: A review, J. Pet. Explor. Prod. Technol., 9 (3), 2091-2107.

[2] Subramanie, P.A.P., Padhi, A., Ridzuan, N., and Adam, F., 2019, Experimental study on the effect of wax inhibitor and nanoparticles on rheology of Malaysian crude oil, J. King Saud Univ. Eng. Sci., In Press, Corrected Proof.

[3] Mansourpoor, M., Azin, R., Osfouri, S., and Izadpanah, A.A., 2019, Experimental investigation of wax deposition from waxy oil mixtures, Appl. Petrochem. Res., 9 (2), 77-90.

[4] Quan, Q., Wang, W., Wang, P., Yang, J., Gao, G., Yang, L., and Gong, J., 2016, Effect of oil temperature on the wax deposition of crude oil with composition analysis, Braz. J. Chem. Eng., 33 (4), 1055-1061.

[5] Meyer, R.F., 1987, Prospects for heavy crude oil development, Energy Explor. Exploit., 5 (1), 27-55.

[6] Fan, K., Huang, Q., Li, S., and Yu, W., 2017, The wax deposition rate of water-in-crude oil emulsions based on the laboratory flow loop experiment, J. Dispersion Sci. Technol., 38 (1), 8-18.

[7] Abdurrahman, M., Ferizal, F.H., Husna, U.Z., and Pangaribuan, L., 2018, Possibility of wax control techniques in Indonesian oil fields, AIP Conf. Proc., 1941(1), 020001.

[8] White, M., Pierce, K., and Acharya, T., 2018, A review of wax-formation/mitigation technologies in the petroleum industry, SPE Prod. Oper., 33 (3), 476485.

[9] Khan, I., Saeed, K., and Khan, I., 2019, Nanoparticles: Properties, applications and toxicities, Arabian J. Chem., 12 (7), 908-931.
[10] Khan, R.N., Ali, N., Riaz, S., and Naseem, S., 2015, Effect of calcination on properties of cobalt doped $\mathrm{ZnO}$ nanoparticles, Mater. Today: Proc., 2 (10, Part B), 5765-5770.

[11] Ashraf, R., Riaz, S., Kayani, Z.N., and Naseem, S., 2015, Effect of calcination on properties of $\mathrm{ZnO}$ nanoparticles, Mater. Today: Proc., 2 (10, Part B), 5468-5472.

[12] Jain, D., and Bihani, A.D., 2014, Crude oil viscosity correlations: A novel approach for Upper Assam Basin, PetroTech 2014: The 11 $1^{\text {th }}$ International Oil and Gas Conference and Exhibition, New Delhi, India, 12-14 January 2014.

[13] Santos, R.G., Loh, W., Bannwart, A.C., and Trevisan, O.V., 2014, An overview of heavy oil properties and its recovery and transportation methods, Braz. J. Chem. Eng., 31 (3), 571-590.

[14] Hasnidawani, J.N., Azlina, H.N., Norita, H., Bonnia, N.N., Ratim, S., and Ali, E.S., 2016, Synthesis of $\mathrm{ZnO}$ nanostructures using sol-gel method, Procedia Chem., 19, 211-216.

[15] He, L., Tong, Z., Wang, Z., Chen, M., Huang, N., and Zhang, W., 2018, Effects of calcination temperature and heating rate on the photocatalytic properties of $\mathrm{ZnO}$ prepared by pyrolysis, J. Colloid Interface Sci., 509, 448-456.

[16] Mornani, E.G., Mosayebian, P., Dorranian, D., and Behzad, K., 2016, Effect of calcination temperature on the size and optical properties of synthesized $\mathrm{ZnO}$ nanoparticles, J. Ovonic Res., 12 (2), 75-80.

[17] Patil, S., and Raut, S.J., 2012, Synthesis and characterization of $\mathrm{ZnO}$ nanoparticles and $50 \%$ ZnO-bentonite nanocomposite, Int. J. Chem. Sci., 10 (2), 1124-1132.

[18] Sunitha, S., Rao, A., and Jayabalan, K., 2015, Synthesis of novel cobalt doped zinc oxide/carbon nano composite for the photocatalytic degradation of acid blue 113, Orient. J. Chem., 31 (1), 107-112.

[19] Al-Hada, N.M., Saion, E.B., Shaari, A.H., Kamarudin, M.A., Flaifel, M.H., Hj Ahmad, S., and Gene, S.A., 2014, A facile thermal-treatment route to synthesize $\mathrm{ZnO}$ nanosheets and effect of calcination temperature, PLoS One, 9 (8), e103134. 
[20] Ismail, A.M., Menazea, A.A., Kabary, H.A., ElSherbiny, A.E., and Samy, A., 2019, The influence of calcination temperature on structural and antimicrobial characteristics of zinc oxide nanoparticles synthesized by sol-gel method, J. Mol. Struct., 1196, 332-337.

[21] Getie, S., Belay, A., Chandra Reddy, A.R., and Belay, Z., 2017, Synthesis and characterizations of zinc oxide nanoparticles for antibacterial applications, $J$. Nanomed. Nanotechnol., S8, 004.

[22] Al-Hada, N.M., Saion, E.B., Shaari, A.H., Kamarudin,
M.A., and Gene, S.A., 2013, The influence of calcination temperature on the formation of zinc oxide nanoparticles by thermal-treatment, Appl. Mech. Mater., 446-447, 181-184.

[23] Ekaputra, A.A., Sabil, K.M., Hosseinipour, A., and Bin Saaid, I., 2014, Impacts of viscosity, density and pour point to the wax deposition, J. Appl. Sci., 14 (23), 3334-3338.

[24] Patel, H., Shah, S., Ahmed, R., and Ucan, S., 2018, Effects of nanoparticles and temperature on heavy oil viscosity, J. Pet. Sci. Eng., 167, 819-828. 